\title{
園芸作物の硝酸塩蓄積に関する研究
}

\section{（第7 報）トマト果実の硝酸塩蓄積に扣よぼす等素肥料の影響（2）}

\author{
宮崎正則・国里 進三・美谷誠一
}

\author{
Studies on the Accumulation of Nitrate in Horticultural Products \\ Part VII. Effects of nitrogen fertilizer on the accumulation \\ of nitrate in tomato fruit (2) \\ Masanori Miyazaki, Shinzo Kunisato and Seitch Miya
}

\begin{abstract}
It is known that nitrate in tomato fruit causes heavy tin-dissolving in canned tomato juice.
In the previous paper, it was reported that the application of the top-dressing of nitrogen increased nitrate content in tomato fruit. The present study was carried out to investigate the influence of the application time of the top-dressing of nitrogen on the accumulation of nitrate in tomato fruit.

While nitrate in soil increased by the application of the top-dressing, the content varied remarkably with the time of application. Considerable amount of nitrate was detected in the fruit grown on high level of nitrate in the soil. Nitrate contents in both soil and fruit increased when the top-dressing had been applied shortly before the beginning of harvest, or three times during the growing period.

(Received Aug. 11, 1971)
\end{abstract}

缶詰トマトジュースのスズ異常溶出の一原因が原料卜 マト果实に含まれる硝酸塩にあり1，スズ溶出防止には トマト果実の硝酸態窒素 (以下 $\mathrm{NO}_{3}-\mathrm{N}$ と記す) 濃度を $3 \mathrm{ppm}$ 以下にしなければならないとされている。そこで トマト果実の $\mathrm{NO}_{3}-\mathrm{N}$ 浱度を $3 \mathrm{ppm}$ 以下にする栽培条 件を見いだすことを目的とし，まず $\mathrm{NO}_{\mathfrak{s}}-\mathrm{N}$ 蓄積の要因 を見いだそうとした。

土堷の $\mathrm{NO}_{3}-\mathrm{N}$ は根に吸収され，すみやかに果実に移 行し', 未熟果実による $\mathrm{NO}_{8}-\mathrm{N}$ の吸収, 蓄積は予想以上 に大きい3)。完熟果の $\mathrm{NO}_{8}-\mathrm{N}$ 蓄積要因として土㙵肥料, 栽培管理, 環境, 品種, 体内生理などの諸条件が考えら れる。前報 ${ }^{4,5)} \mathrm{N}$ 肥料の影響について検討し， $\mathrm{N}$ 追 肥が描積に影響する傾向が認められたので, 1969 年と 1970 年に砂耕, 粗場栽培で $N$ 追肥の影響 とくに追肥施 用時間の影響について検討した。

\section{実 験 方 法}

1. 砂 耕

トマト品種“大豊”を用い, 1969 年 3 月 5 日播種し,
4 月 17 日ガラス室および人工気象室内の砂耕用ポット $\left(\frac{1}{2000} \mathrm{a}\right)$ に定植した。処理区は培養液の $\mathrm{NO}_{3}-\mathrm{N}$ 濃度 $210 \mathrm{ppm}$ 区 (標準)，840 ppm 区 (高䟴度区)，105 $210 \mathrm{ppm}$ 区（低濃度と標準濃度に 1 週間毎に変化させる 区)，105 “840 ppm 区（低濃度已高濃度に 1 週間毎に 変化させる区)，1段花房 1 番花の開花後，1,2 週目，3， 4 週目，5,6週目，7,8週目の各 2 週間のみ $840 \mathrm{ppm} に$ し，他の時期は $105 \mathrm{ppm}$ にする区および 1 段果房 1 番

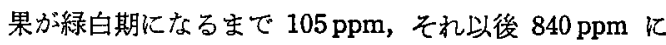
する 105 —840 ppm 区を設けた。標準培養液組成は N $\left(\mathrm{NO}_{8}-\mathrm{N}\right.$ で与え, $\mathrm{KNO}_{8}, \mathrm{Ca}\left(\mathrm{NO}_{8}\right)_{2} \cdot 4 \mathrm{H}_{2} \mathrm{O}$ で作成) 210 ppm, $\mathrm{P}\left(\mathrm{KH}_{2} \mathrm{PO}_{4}\right) 31 \mathrm{ppm}, \mathrm{K}\left(\mathrm{KNO}_{3}, \mathrm{KH}_{2} \mathrm{PO}_{4}\right) 234$ ppm, $\mathrm{Ca}\left(\mathrm{Ca}\left(\mathrm{NO}_{8}\right)_{2} \cdot 4 \mathrm{H}_{2} \mathrm{O}\right) 200 \mathrm{ppm}, \mathrm{Mg}\left(\mathrm{MgSO}_{4} \cdot 7\right.$ $\left.\mathrm{H}_{2} \mathrm{O}\right) 48 \mathrm{ppm}, \mathrm{Fe}$ (クェン酸鉄として) $8 \mathrm{ppm}, \mathrm{B}\left(\mathrm{H}_{3}\right.$ $\left.\mathrm{BO}_{3}\right) 0.5 \mathrm{ppm}, \mathrm{Mn}\left(\mathrm{MnCl}_{2} \cdot 4 \mathrm{H}_{2} \mathrm{O}\right) 0.5 \mathrm{ppm}$, $\mathrm{Mo}\left(\mathrm{Na}_{2}\right.$ $\left.\mathrm{MoO}_{4} \cdot 2 \mathrm{H}_{2} \mathrm{O}\right) 0.05 \mathrm{ppm}, \mathrm{Zn}\left(\mathrm{ZnSO}_{4} \cdot 7 \mathrm{H}_{2} \mathrm{O}\right) 0.05 \mathrm{ppm}$, $\mathrm{Cu}\left(\mathrm{CuSO}_{4} \cdot 5 \mathrm{H}_{2} \mathrm{O}\right) 0.02 \mathrm{ppm}$ とし, $\mathrm{pH}$ 任 5.8〜6.0 K 調整した。 $\mathrm{NO}_{8}-\mathrm{N}$ 女高濃度にするには, $\mathrm{NaNO}_{8}$ を加え， 低浱度にするには $\mathrm{KNO}_{3}, \mathrm{Ca}\left(\mathrm{NO}_{3}\right)_{2} \cdot 4 \mathrm{H}_{2} \mathrm{O}$ を減じ,

東洋食品研究所 (兵庫県川西市南花屋敷 4-23)

Toyo Institute of Food Technology. 4-23 Minamihanayashiki, Kawanishi-shi, Hyogo, Japan. 
第 1 表 気象室の条件

\begin{tabular}{|c|c|c|c|c|c|c|}
\hline \multirow{2}{*}{ 日变化琮) } & \multirow{2}{*}{ 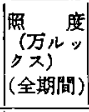 } & \multicolumn{5}{|c|}{ 温 $\left(c^{\circ}\right)$} \\
\hline & & 4,5 月 & 6月前期 & 6月後期 & 7月前期 & 7月後期 \\
\hline $6.00 \rightarrow 8.30$ & 3 & 20 & 22 & 23 & 24 & 23 \\
\hline $8.30 \rightarrow 10.00$ & 5 & 23 & 24 & 25 & 27 & 26 \\
\hline $10.00 \rightarrow 15.00$ & 7 & 26 & 27 & 28 & 30 & 30 \\
\hline $15.00 \rightarrow 17.00$ & 5 & 23 & 24 & 25 & 27 & 26 \\
\hline $17.00 \rightarrow 19.00$ & 3 & 20 & 22 & 23 & 24 & 23 \\
\hline $19.00 \rightarrow 5.00$ & 0 & 17 & 20 & 21 & 20 & 20 \\
\hline
\end{tabular}

$\mathrm{KCl}, \mathrm{CaCl}_{2} \cdot 2 \mathrm{H}_{2} \mathrm{O}$ を加え， $\mathrm{K}, \mathrm{Ca}$ 浱度を調整した。株 は整技 3 段果房止めとし，1 区 3 株を $20 l$ の培盖液で䏍 て，1 週間毎に更新した。人工気象室は Tem-Con（大阪 冷機工業株式会社製) を使用した。気温は長野県のトマ 卜産地の気温它トマトの生育状態に応じて第 1 表のよう に日変化と時期変化させた。照明はレフランプと䖝光水 銀灯の人工光を用い，全期間同一の日变化を行なった (第 1 表)。

\section{2. 畕場栽培}

品種“チュ”, “Heinz 1370”, “大豊”案用い, 1969 年 3 月 3 日播種し，4月 30 日にやや粘土質で，防疫のた め冬期間湛水した土塬に定植した。 $\mathrm{N}$ 追肥施用時期の影 響をみるため, $\mathrm{N}$ 施肥量の $40 \%$ を元肥として与え，残り
$60 \%$ 定植 2 週間後，4 週間後，6 週間後，8週間後に与 える区（以下 $\times$ 週後区と記す）拉よび 4,6，8 週間後の 3 回に分施する区（以下分施区と記す）を設けた。標淮 施肥量法 $\mathrm{N}$ (硫安): $\mathrm{P}$ (溶性リン肥): $\mathrm{K}$ (塩加)を“委 コ”と “Heinz 1370”で 25:30:30 kg/10a, “大豊” で 40:32:30 kg/10a とした。とのうち N と K は 40\% を元肥，60\%を追肥とした。なお全区に廐肥 $4 \mathrm{t} / 10 \mathrm{a}$ ， 苦土石灰 $150 \mathrm{~kg} / 10 \mathrm{a}$ を与えた。“チコ”と“Heinz 1370 "注うね巾 $1.2 \mathrm{~m}$ ，株間 $0.45 \mathrm{~m}$ のボリマルチ無支 柱栽培とし, “大豊”はうね巾 $1.8 \mathrm{~m}$, 株間 $0.45 \mathrm{~m} の$ ポりマルチ有支柱栽培を行なった。定 植 前の4月22日 および定植後 2 週間每（追肥の前日）に地上部と土壤 (“チコ”と“Heinz 1370”はうねの肩部の地下 $10 \mathrm{~cm}$ の土壤安同一区 3 ヶ所, “大豊”は株間の地下 $10 \mathrm{~cm} の$ 土壤）を採取し， $\mathrm{NO}_{3}-\mathrm{N}$ 量を測定した。

1970 年には“チコ”と“FR 1 号”(有支柱品種)を 用い，3月5 日播種し，5月6日に定植した。処理区は $\mathrm{N}$ 施肥量の $40 \%$ を元肥と乙て与え，残り $60 \%$ を定植後 2 週間後， 4 週間後，6週間後に追肥する区および $2,4,6$ 週間後に 3 回に分施する区它設けた。なお対照として全 量元肥区，少量元肥区（標準 $N$ 量の $40 \%$ ）をも設けた。 他は 1969 年度に準ずる。

3. 分析方法

$\mathrm{NO}_{8}$-N の分析は WOLLEY らの方法"使用した。果

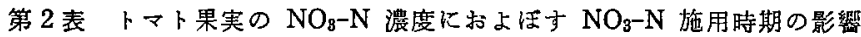

\begin{tabular}{|c|c|c|c|c|c|c|}
\hline \multirow{3}{*}{ 垛萑做の $\mathrm{NO}_{\mathrm{s}}-\mathrm{N} \quad(\mathrm{ppm})$} & \multicolumn{4}{|c|}{$\mathrm{NO}_{3}-\mathrm{N}(\mathrm{ppm})$} & & \\
\hline & \multicolumn{2}{|c|}{ 粶自期 } & \multicolumn{2}{|c|}{ 完熱 } & & \\
\hline & 柄 & 1 段 1 覃畏 & 1 段 1 番果 & 1 段 2 番果 & & \\
\hline 210 & 1110 & 5.1 & 3.1 & 1.4 & H $=x$ & 室. \\
\hline 840 & 790 & 4.6 & 1.0 & 0.5 & & \\
\hline $105 \rightleftarrows 210$ ( 1 逜每のくりかえし） & 1060 & 9.0 & 5.8 & 4.8 & & \\
\hline $105 \rightleftarrows 840$ (1摆每のくりがえし) & & 8.0 & 3.0 & 5.8 & & \\
\hline $105 \rightleftarrows 840$ (1 番花舅花後 $\quad 1,2$ 速のみ 840$)$ & 710 & 5.8 & 4.4 & 2.8 & & \\
\hline $105 \rightleftarrows 840$ (1 委花開花後 $3 ， 4$ 週のみ 840) & 1010 & 4.5 & 2.8 & 2.4 & & \\
\hline $105 \approx 840$ (1 番花䣲花後 $\quad 5,6$ 週のみ 840$)$ & 740 & 8.0 & 3.4 & 3.4 & & \\
\hline $105 \rightleftarrows 840$ (1 番花開花㷋 $\quad 7,8$ 迶のみ 840 ) & 1280 & 5.8 & 3.1 & 2.3 & & \\
\hline $105 \approx 840$ (1 番花聞花後 $1,3,5$ 通のみ 840$)$ & 900 & 5.0 & 2.8 & 0.5 & & \\
\hline 210 & 1590 & 5.6 & 5.1 & 4.9 & 突 & 室 \\
\hline 840 & 1610 & 8.0 & 3.4 & 1.0 & & \\
\hline $105 \rightarrow 840(1$ 番果悢白後 840$)$ & 1340 & 9.8 & 3.5 & 1.4 & & \\
\hline 105 840 (1 週毎のくりがえし) & 1320 & 12.5 & 4.2 & 5.9 & & \\
\hline
\end{tabular}

(1969. 品種“大䅧”, 砂耕) 


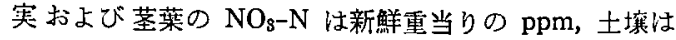
風乾土の ppm で表示した。

\section{実 験 結 果}

\section{1. 砂耕の結果}

“大豊” の果実の $\mathrm{NO}_{8}-\mathrm{N}$ 濃度汅招よぼす培地の $\mathrm{NO}_{3}-$ $\mathrm{N}$ 施用時期の影響第 2 表に示す。2, 3 段果房の完熟果 实の $\mathrm{NO}_{3}-\mathrm{N}$ 浱度は $1 \mathrm{ppm}$ 以下であったので記载しな かった。ガラス室栽培では標準区と変化区（1 週間毎） は $\mathrm{NO}_{3}-\mathrm{N}$ 高浪感区より高い傾向を示した。2 週間のみ

の $\mathrm{NO}_{3}-\mathrm{N}$ 高浱度処理では, 1, 2 週目処理区と 5, 6 週目 処理区がやや高い傾向を示したが大差は認められなかっ た。人工気象室栽培で怔準区と变化区が高く，緑白期 以降の $\mathrm{NO}_{3}-\mathrm{N}$ 高浱度処理区はやや低い値を示した。

緑白果の $\mathrm{NO}_{3}-\mathrm{N}$ 濃度は完熟果より高いが, 標準区の ように大差がない場合も認められた。

\section{2. 圃場栽培の結果}

1969 年の “チュ”, “Heinz 1370”と“大豊”の茎 葉および土壤の $\mathrm{NO}_{3}-\mathrm{N}$ 搌度の变化および収㮃日每の完 熟果の $\mathrm{NO}_{3}-\mathrm{N}$ 濃度を第 1 四および第 2 図化示与。なお “チコ” と “Heinz 1370” の

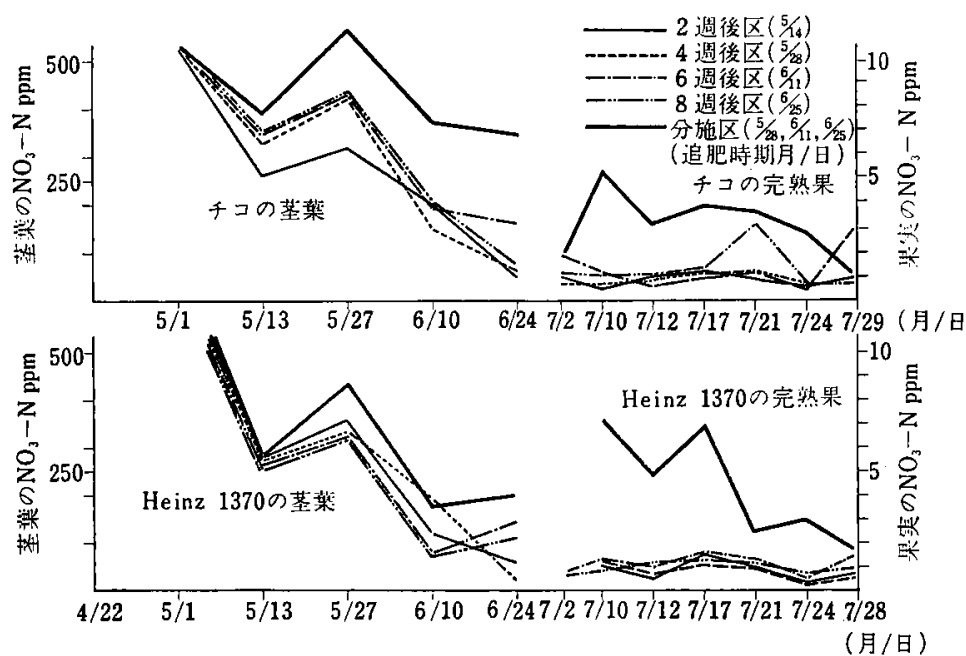

第 1 図トマトの荎葉括よび完熟果の $\mathrm{NO}_{3}-\mathrm{N}$ 泷度におよほす $\mathrm{N}$ 追肥施用時期の影箤 (1969)

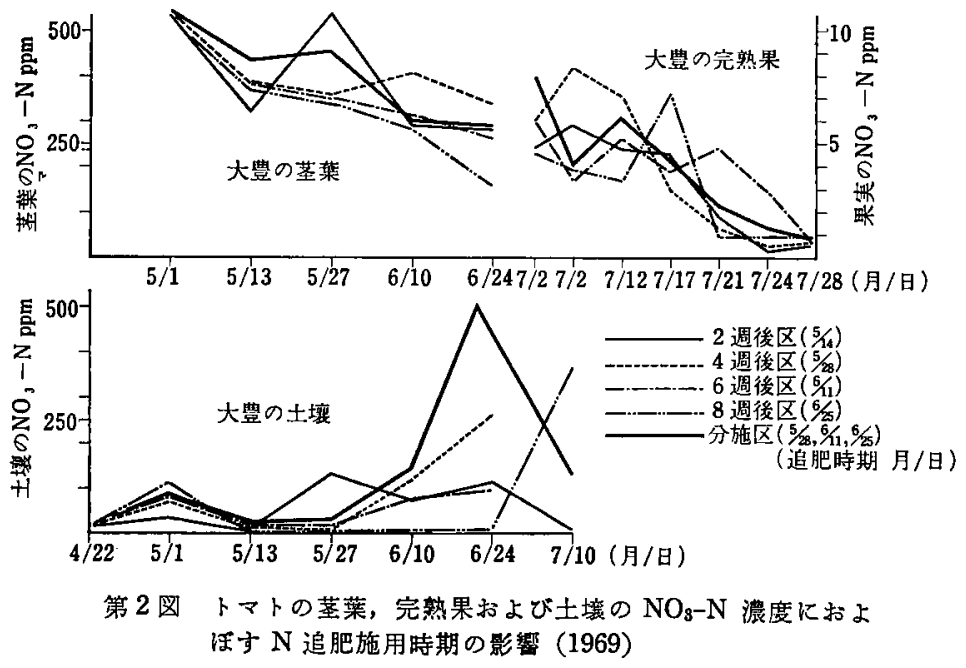

土塨の $\mathrm{NO}_{3}-\mathrm{N}$ 濃度はいずれの 区も，いずれの時期にも $50 \mathrm{ppm}$ 以下であり，区間毎の差異が 認められなかったので図示しな かった。

茎葉の $\mathrm{NO}_{3}-\mathrm{N}$ 濃度は“チコ” では定植 2 週間後には加なり低 下し，その後やや增加するが， 分施区が常に高い傾向を示し た。“Heinz 1370”は“チコ, に比べて濃度はやや低いが，分 施区が他の区に比べやや高い傾 向を示した。“大豊”では 2 週 間後市よび 4 週間後の追肥で茎 葉の $\mathrm{NO}_{3}-\mathrm{N}$ 洋度の增加が認め られたが，6週間後の追肥では その影㗽が認められなかった。

土壤の $\mathrm{NO}_{8}-\mathrm{N}$ 濃度は“大豊” では，いずれの時期の追肥でも 追肥後に堌加が認められたが， 施用時期の違いにより増加量に 差異があり，2週後区と 6 週 後区は低く，4週後区，8週後 区，分施区はかなり高い值を示 した。

第 3 表に収穫 1 週間前（6月 24 日)の菱葉と末熟果の重量お よび $\mathrm{NO}_{3}-\mathrm{N}$ 浱度を示市。“千 コ”では茎葉の $\mathrm{NO}_{9}-\mathrm{N}$ 濃度は 分施区が最も高く，次いで 6 週 後区が高く,6月24日にはまだ追 肥されていない 8 週後区とすで に追肥されている4 週後区と 2 


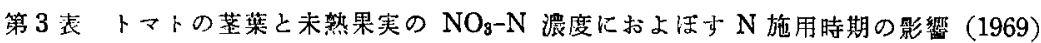

\begin{tabular}{|c|c|c|c|c|c|c|c|c|c|c|c|c|}
\hline & \multirow{4}{*}{ 昭然と追肥施用洔期（月/日） } & \multicolumn{2}{|c|}{ 5月1日(定植時) } & \multicolumn{9}{|c|}{ 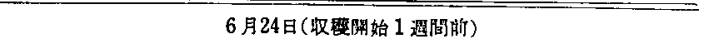 } \\
\hline & & 莁 & 葉 & 洼 & 蕉 & \multicolumn{3}{|r|}{ 未 } & 熟 & 斐 & & \\
\hline & & \multirow{2}{*}{\multicolumn{2}{|c|}{ 重 $\mathrm{NO}_{3} \cdot \mathrm{N}$}} & \multirow{2}{*}{\multicolumn{2}{|c|}{ 望 $\mathrm{NO}_{3} \cdot \mathrm{N}$}} & & \multicolumn{2}{|c|}{1 段 1 番果 } & \multicolumn{2}{|c|}{2 卯 I 畄果 } & \multicolumn{2}{|c|}{3 段1番果 } \\
\hline & & & & & & 全重量 & 需 & $\overrightarrow{\mathrm{O}_{3}-\mathrm{N}}$ & 重 & $\overline{\mathrm{O}_{3}-\mathrm{N}}$ & 画盘 & $\overline{\mathrm{O}_{3}-\mathrm{N}}$ \\
\hline \multirow{5}{*}{$f=$} & 2 迴後区 $(5 / 14)$ & $\underset{45}{8 / 16}$ & $539^{\mathrm{pmm}}$ & $\begin{array}{l}\mathbf{g} / 1 \text { 林 } \\
880\end{array}$ & $\mathrm{ppm}_{50}$ & $\begin{array}{l}\text { g/l 株 } \\
1197\end{array}$ & $\frac{g / 1 \text { 株 }}{45}$ & $\begin{array}{l}\mathrm{ppm} \\
2.4\end{array}$ & $\frac{g / 1}{41}$ & $\begin{array}{c}\mathrm{ppm} \\
1.6\end{array}$ & $8 / 16$ & $\begin{array}{l}\mathrm{ppm} \\
2.4\end{array}$ \\
\hline & 4 遗後区 $(5 / 28)$ & & & 770 & 53 & 1705 & 52 & 1.6 & 39 & 2.4 & 41 & 1.2 \\
\hline & 6 遗媵区 $(6 / 11)$ & & & 1360 & 163 & 1409 & 51 & 4.2 & 43 & 3.6 & 32 & 4.4 \\
\hline & 8 週後区（6/25) & & & $12 € 0$ & 73 & 1707 & 46 & 2.9 & 55 & 1.2 & 48 & 1.2 \\
\hline & 分施区 $(5 / 28,6 / 11,6 / 25)$ & & & 1910 & 350 & 1431 & 48 & 6.4 & 42 & 9.2 & 33 & 5.2 \\
\hline \multirow{5}{*}{$\begin{array}{c}\text { Heinz } \\
1370\end{array}$} & 2 迅後区 $(5 / 14)$ & 28 & 669 & 1170 & 59 & 856 & 41 & 1.6 & 58 & 1.0 & 47 & 1.1 \\
\hline & 4 週後区 $(5 / 28)$ & & & 1160 & 23 & 699 & 42 & 1.0 & 63 & 0.9 & 46 & 1.2 \\
\hline & 6 週後区 $(6 / 11)$ & & & 1470 & 142 & S72 & 56 & 4.2 & 44 & 3.2 & 39 & 0.9 \\
\hline & 8 週後区 $(6 / 25)$ & & & 1480 & 116 & 856 & 71 & 2.2 & 63 & 2.2 & 56 & 1.6 \\
\hline & 分施区 $(5 / 28,6 / 11,6 / 25)$ & & & 2060 & 198 & 775 & 88 & 3.2 & 68 & 4.0 & 39 & 2.4 \\
\hline \multirow{5}{*}{ 大祡 } & 2 遏绻区 $(5 / 14)$ & 53 & 541 & 790 & 280 & 905 & 105 & 6.4 & 32 & 5.2 & 85 & 2.4 \\
\hline & 4 逻後区 $(5 / 28)$ & & & $8 \subseteq 0$ & 340 & 977 & 116 & 6.8 & 63 & 9.2 & 78 & 4.0 \\
\hline & 6 通後区 $(6 / 11)$ & & & 880 & 264 & 781 & 83 & 9.6 & 56 & 9.2 & 89 & 6.3 \\
\hline & 8 迅後区 $(6 / 25)$ & & & 890 & 165 & 689 & 113 & 4.0 & 58 & 2.4 & 65 & 1.1 \\
\hline & 分施区 $(5 / 28,6 / 11,6 / 25)$ & & & 680 & 290 & 864 & 114 & 8.4 & 88 & 9.2 & 32 & 4.8 \\
\hline
\end{tabular}

週後区はかなり低い值を示した。茎葉の生育は分施区と 6 週後区は良好であり，8週後区でもかなり良好であっ た。未熟果の $\mathrm{NO}_{3}-\mathrm{N}$ 濃度は分施区と6 週後区が高い傾 向を示した。“Heinz 1370”の茎葉の $\mathrm{NO}_{3}-\mathrm{N}$ 浱度は 分施区が高く, 未熟果の $\mathrm{NO}_{3}-\mathrm{N}$ 漂度も分施区で高い が，他の区に比べて大きな差ではならった。“大豊”て は茎葉の $\mathrm{NO}_{3}-\mathrm{N}$ 浱度は 4 週後区が最も高く, 6 月 24 日 にはまだ追肥されていない8週徭区が最も低く，未熟果 の $\mathrm{NO}_{3}-\mathrm{N}$ 濃度は 4 週後区, 6 週後区, 分施区が高く, 8 週後区は低い傾向を示した。

完熟果の $\mathrm{NO}_{\mathrm{g}}-\mathrm{N}$ 濃度（第1図および第 2 図）法“チ コ”では分施区が高く，収穫中期以降漸隇した。6 週後 区と8 週後区では収穫中期にやや増加寸る傾向も認めら れた。“Heinz 1370”では分施区で収穫初期に高く, そ の後急減した。他の区はいずれも $2 \mathrm{ppm}$ 以下であった。 “大豊”では各区とも最高值は $5 \mathrm{ppm}$ 以上を示したが, 分施区，4週後区が比較的高く，2 週後区，6 週後区は やや低く, 8 週後区はピークがやや集れる傾向を示した。

1970 年の“チュ”之“FR 1 号”の完熟果の $\mathrm{NO}_{3}-\mathrm{N}$ 濃度第 3 図に示す。“チュ”双篗初期に高く（7月 6 日は収穫初日であり, 完热果数は 40 株中約 10 個程度 であった)，その後急減し，收穕中期にやや増加する傾
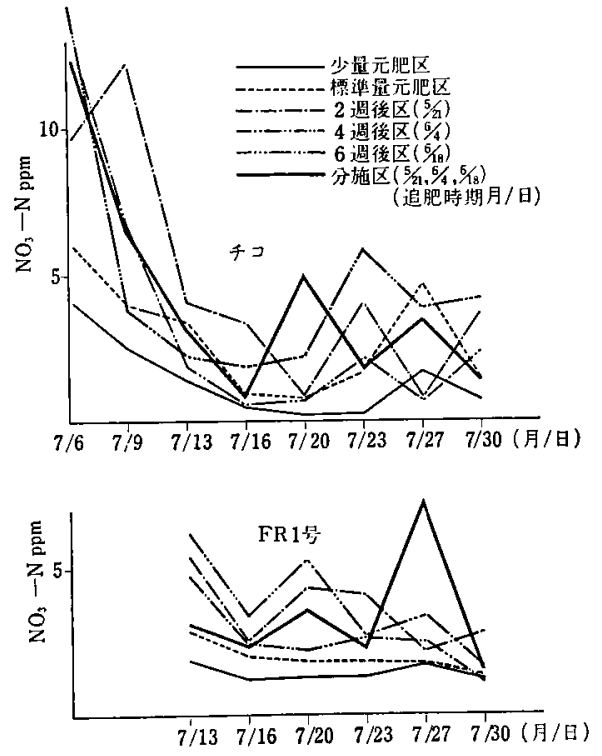

第3四トマト完熟果の $\mathrm{NO}_{3}-\mathrm{N}$ 濃度に的よぼす $\mathrm{N}$ 追肥施用時期の影鄉（1970）

向が認められた。収穫初期において汪少量元肥区、標準 量元肥区は追肥区に比べかなり低く，かつ追肥区にむい 


\begin{tabular}{|c|c|c|c|c|c|c|}
\hline \multicolumn{2}{|c|}{ 第 4 表 } & 二壤の & \multicolumn{3}{|c|}{ D $\mathrm{NO}_{8}-\mathrm{N}$ 湄度の変化 } & \multirow{2}{*}{$\frac{(\mathrm{ppm})}{7 \text { 月14日 }}$} \\
\hline 践孯区 & 5 月11日 & 5 月20日 & 6 月 1 日 & 6月17日 & 6 月30日 & \\
\hline 分海区 & 76 & 182 & 220 & 220 & 30 & 20 \\
\hline 1. & 114 & 230 & 160 & 100 & 17 & 17 \\
\hline 2. & 60 & 123 & 270 & 175 & 70 & 9 \\
\hline
\end{tabular}

てはいずれの時期の追肥区も高く区間の差異は認められ なかった。“FR 1号”注分施区がとくに中期に高く，て の点“チコ”とはやや異なる傾向を示した。

1970 年の土塨の $\mathrm{NO}_{3}-\mathrm{N}$ 浱度は実験の各区については 測定しなかったが、“チュ”の分施区および参考のた内 同年同一区画の土塞の $\mathrm{NO}_{3}-\mathrm{N}$ 濃度（第 4 表の 1,2 ）を 第 4 表に示した。 5 月中旬加ら 6 月上，中旬にかけて 高搌度であったが, 収繁開始の7月6日にはかなり低下 し，1969 年の“大豊”の分施区とはやや異なる傾向岂 示した。

\section{考察}

数年前に発生したオレンジジュース缶詰のスズ異常溶 出事故はジュース缶詰製造時に使用される調合用水中に 含まれていた硝酸塩に基因し，ジュース年詰の調合用水 中の $\mathrm{NO}_{3}-\mathrm{N}$ は $1 \mathrm{ppm}$ 以下, シラップ調合用水中では $5 \mathrm{ppm}$ 以下が望ましいと報告されている7(8)91。100\% 果 汁のトマトジュース缶詰でもスズ異常溶出事故が発生 し，これも原料トマト果実中に含まれる硝酸塩に基因 し，果実の $\mathrm{NO}_{8}-\mathrm{N} 3 \mathrm{ppm}$ 以下にしなければならない とされている。パインフップル，バナナ，プリンスメロ ン，ホーレンソウ，グリーン・ビーンズでも硝酸塩によ るスズ異常溶出が発生する ${ }^{10} 11$ 。硝酸塩によるスズ異常 溶出防止には製造工程中での硝酸塩の除去, 添加物によ る硝酸塩の除去, 耐腐食性の強い午の使用之同時に硝酸 塩の少ない原料の使用の必要があり, 現在は脱イオン水 の使用，各種の塗装午の使用，原料中の硝酸塩の千ェッ クか行なわれている。

著者らは数年来, 原料中の $\mathrm{NO}_{3}-\mathrm{N}$ 濃度を低下させる 栽培法を見いだそうとして，トマト果実の硝酸塩蓄積の 要因を検討してきた。

トマト果実の $\mathrm{NO}_{3}-\mathrm{N}$ 蓄積に関し, 阿部 ${ }^{121}$, 高橋 ら゙のの報告があるが，N施肥量の影響は明らかでない。 トマトは第1段果房の肥大期から養分吸収量が增加 (14:15)，定植後，2ないし 3 ケ月の間に大部分が吸収さ

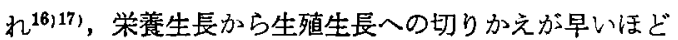

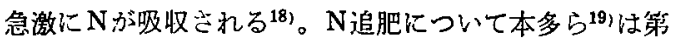

1 および第 3 果房肥大期の $\mathrm{NO}_{3}-\mathrm{N}$ 高浪度処理は果実の $\mathrm{NO}_{8}-\mathrm{N}$ 濃度を高的るとしているが，本実馱の砂耕では 果実の $\mathrm{NO}_{3}-\mathrm{N}$ 濃度におよぼす $\mathrm{NO}_{8}-\mathrm{N}$ 高濃度処理時期 の影響は明らかでなく，培地の $\mathrm{NO}_{8}-\mathrm{N}$ 濃度の数回の变 化が影響する傾向が認められた。この傾向は國場の追肥 区の果実に $\mathrm{NO}_{8}-\mathrm{N}$ が蓄積する傾向と類似すると考えら れる。しかし直場の追肥区における果実の $\mathrm{NO}_{8}-\mathrm{N}$ 蓄積 は追肥により土壤の $\mathrm{NO}_{8}-\mathrm{N}$ 濃度が増加し，かつ長期間 維持されることによると推察されるので，砂耕におけ る $\mathrm{NO}_{8}-\mathrm{N}$ 濃度変化区に打ける果実の $\mathrm{NO}_{8}-\mathrm{N}$ 蓄積は $105 \rightleftarrows 210 \mathrm{ppm}$ 区では培地の $\mathrm{NO}_{3}-\mathrm{N}$ 罣度以外の要因 例へば養分の不均衡などが影嘼したと考えられる。

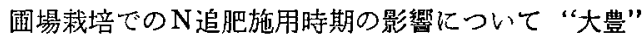
みると，茥葉の $\mathrm{NO}_{3}-\mathrm{N}$ 濃度の低い 8 週後区は 6 月 24 日まで追肥されず，土壤の $\mathrm{NO}_{3}-\mathrm{N}$ 濃度も著しく低 く,このことは未熟果の $\mathrm{NO}_{\mathfrak{a}}-\mathrm{N}$ 濃度の低いこととも 関連すると考えられる。6 月 25 日の追肥の後の土壌の $\mathrm{NO}_{8}-\mathrm{N}$ の急増は完熟果の $\mathrm{NO}_{3}-\mathrm{N}$ 濃度がかなり高く, し かもそのピークが他の区に比べてやや途れたことと関連 すると考えられる。2 週後区と6 週後区は土境, 茎葉, 完熟果の濃度は低く，4 週後区と分施区は高く,追肥によ り土壤の $\mathrm{NO}_{8}-\mathrm{N}$ 浱度が高くなった区は果実の $\mathrm{NO}_{8}-\mathrm{N}$ 浱度が高くなる傾向が認められた。しかし同年度，同一 甬場で $\mathrm{N}$ 追肥施用時期の違いにより土壤の $\mathrm{NO}_{8}-\mathrm{N}$ 濃度 に差異が生じたこと，年度の違いにより差異の生じ得る 可能性が大であることからいずれの時期の N追肥がト、 卜果実の $\mathrm{NO}_{3}-\mathrm{N}$ 濃度に影響するかは明確には言い切れ ない。

1969 年度の“チュ”と “Heinz 1370”はいずれの時 期の追肥でも 1 回の追肥では果実の $\mathrm{NO}_{8}-\mathrm{N}$ 澷度が低 く,“大豊”ではかなり高い值を示した。この原因は無 支柱品種と有支柱品種の違い，施肥量の違い，追肥施用 位置の違い(“大豊”はうねの中央部に, “チコ”と “Heinz $1370 ”$ はうね間のみぞに施用) から生じたも のと考えられる。

1970 年度の“チュ”は 1 回の追肥でもかなりの $\mathrm{NO}_{9}$ $\mathrm{N}$ 蓄積量を示し，1969 年度とは明らかに異なった傾向 を示した。この原因として两年度の環境条件，土垷の $\mathrm{NO}_{8}-\mathrm{N}$ 濃度とその時期姿化などが考えられるが明らか でない。

要 約

1.トマト果实の $\mathrm{NO}_{8}-\mathrm{N}$ 濃度におよぼす $\mathrm{N}$ 追肥施用 時期の影響について検討した。 
2. $\mathrm{N}$ 追肥により土塨の $\mathrm{NO}_{3}-\mathrm{N}$ 濃度は増加するが, 施用時期の違いにより検出量にかなりの差異が認められ た。

3. 3 回の追肥施用之収權開始時期汇近い時期の追肥 施用は土缺の $\mathrm{NO}_{3}-\mathrm{N}$ 䟴度を高め, 果実の $\mathrm{NO}_{8}-\mathrm{N}$ 濃段: も高めた。

この研究に際し, 有益な御助言を頂いた東洋食品研究 所堀尾募友主任研究員, 岩本喜伴主任研究員, 東洋食品 工業短期大学大塚滋教授，下田吉夫譜師に感謝致しま す。また御助力頂いた東洋食品研究所本多武雄研究員, 杉原八郎, 䔩内一雄, 若狭勝副研究員に感謝致します。

\section{文献}

1）岩本喜伴・宮崎正則・国里進三・前田琇子・堀尾 嘉友・小林祥子：柴㦈之食糧，21，50 (1968).

2) 宮猗正則 - 国里進三・美谷誠一・石川 伸: 東洋 食品工業短期大学・東洋食品研究所研究報告書, 9, 278 (1970).

3）宫䗁正則 - 国里進三・美谷誠一・石川 伸：東洋 食品工業短期大学・東洋食品研究所研究報告書： 9, 284 (1970).

4) 宮崎正則 - 国里進三・岩本喜伴・堀尾嘉友：園学 雑, 37, 84 (1968).

5）宮崎正則 - 国里進三・美谷誠一一石川 伸：東洋
食品工業短期大学: - 東洋食品研究所研究報告書, 9, 289 (1970).

6) Woolley, J.T., Hicks, G,P. and Hageman, R. H.: J. Agr. and Food. Chem. 8, 481 (1960).

7）堀尾骞友・岩本密伴・小田久三：食衛誌，6，353 (1965).

8）堀尾喜友・岩本喜伴・小田久三：食衛誌，6，358 (1965).

9）岩本喜伴・堀尾嘉友 - 小村祥子 - 前田琇子：食衛 誌, 8, 494 (1967)

10）岩本喜伴 - 宮崎正則 - 国里進三・前田璠子 ・堀尾 嘉友：栄盖之食得，21，47(196).

11）岩本喜伴 - 宮崎正則 - 前田琇子 - 堀尾嘉友：栄薂 之食軖，23，213 (1970).

12）阿部勇・施山紀男・遠藤敏夫・逸見俊五：昭和 44年度園芸学会秋季大会発表要旨, 290 (1969).

13）高橋和彦・幸田浩俊：食品工誌，17，1（1970）。

14）綿原孝夫：農及園，44，513 (1969).

15) 近藤隆彦：農及園，40，801 (1965).

16) Hester, J.B., Shelton, F.A. and Isacs, R.L.: Amer. Soc. Hort. Sci., 57, 249 (1951).

17) Hester, J.B. and Riverter, N.T.: Amer. Soc. Hort. Sci., 36, 720 (1938).

18）小林忠和：農及園, 45, 41 (1970).

19）本多藤雄・安井秀夫：園試久留米支場昭和 44 年度 試験成稹, 74 (1969).

(昭和 46 年 8 月 11 日受理) 